\title{
Effect of Process Innovations on Financial Performance of Commercial Banks in Kenya
}

\author{
David Waiganjo Waweru ${ }^{1 *}$ Prof. Sun Guang Guo ${ }^{1} \quad$ Abdurahman Aliyi $^{1}$ \\ Jonela Wilson $^{2} \quad$ Mussie Tesfay $^{2}$ \\ 1. School of Accounting, Dongbei University of Finance and Economics, \\ Sha He kou District, Dalian 116025, China \\ 2. School of management, Dongbei University of Finance and Economics, \\ Sha He kou District, Dalian 116025, China
}

\begin{abstract}
Process innovations positively influence the firm's performance and ultimately influence the industry's performance and interactions. This study aimed to evaluate the effect of identified process innovations as independent variables on the financial performance as dependent variables in Kenyan commercial banks using panel data for the period from 2014 to 2018 . The study assessed the performance of the commercial banks during the pre-innovation period of 2009 to 2013 using return on assets the performance measure and compared the performance during the two periods. Based on the analysis results, firms' performance as measured by the return on assets (ROA) improved during the post innovations period as compared to pre-innovations period as per the calculated $\mathrm{p}$ - values. The findings show that mobile banking transactions, agency banking transactions and internet banking transactions controlled by the firm size and leverage positively affect the financial performance of commercial banks in Kenya. Further, it can be deduced that in order to harness efficiency and operational effectiveness, banks need to be innovative to provide better service to their customers, save on costs, tap markets towards competing effectively. The study evaluated the commercial banks in Kenya especially those whose data on innovation activities was available. The F-statistics test was used to test the validity of the variables and the model used. However, though the findings of the study were positive, further research should be conducted especially focusing on the effects of other forms of innovations (product innovation, marketing and organization innovation) and evaluate how they influence firms performance using other performance measures and incorporating other variables like ownership structures, capital structures or corporate governance measures as either mediating or moderating variables.
\end{abstract}

Keywords: Innovation activities, financial institutions, financial inclusion, mobile banking, internet banking and agency banking.

DOI: $10.7176 / \mathrm{JESD} / 10-20-03$

Publication date:October $31^{\text {st }} 2019$

\section{Introduction}

Innovation is the process of implementing original or expressively enhanced process, good or service, organizational method or marketing method in workplace organization, business operations and practices, or external relations (Manual, 2005). In order for innovation to be valid, the marketing method, product, organizational method or process should either be significantly improved or new to the firm (Zhao and Sun 2016). Innovation activities are all scientific, technological, institutional or monetary and viable phases which facilitate the actualization of innovation (Manual 2005). Further, the costs for research and development (R\&D) is incorporated in to innovative activities through its not attached to any specific innovation. (Wang, Hang et al. 2016). Eurostat (2005) point out that innovation types can be in form of product, marketing, process and organizational innovation. In relation to the product innovation the development or improvement of a good or service has to be based on its features or proposed purpose. On the other hand, process innovation involves the implementation and improving delivery or production method which may either involve changing techniques, software or equipment. The process innovations objectives may be to deliver new products, increase quality, decrease unit production or delivery costs and produce or products that have been significantly improved (Wang, Hang et al. 2016).

Innovation in technology is the ultimate driving force of industrial evolution (Yang and Lan 2010). Different economic sectors are key in catalyzing development through innovativeness. For example, the financial sector contributes an immense part in economic environment. Firms within the financial sector provide financial products, services for payments and enables the individual households and firms to contribute to the market activities in a broader way. Further, Dean (1986) explain the concept of innovation as "the driving force for development". Similarly, Vyas (2009) point out five key innovation indicators being: opening of new market, qualitative enhancements in prevailing products towards creating new products, application for new process at the industries, establishment of new sources for raw material and other innovative inputs and; new types of business organizations. Innovation is defined in Eurostat (2005) from the perspective of implementing new products which have been 
significantly improved (either goods or service), a new administrative technique or marketing technique within the business practices, process, office organization or peripheral relations.

Banks for example deal with the enhancement of the payment mechanisms, management and transfer of risks, facilitation of transfer in the financial markets and evaluation and assessment of the behaviors of the financial institutions (Lawson and Samson 2001). Though the essential functions carried out by the financial institutions have constantly been the same over the last decade, the systems and structures of the larger industry have drastically transformed. This has been catalyzed by the liberalization of regulations, global competition growth of innovation and inventions of new financial instruments and increased use of information technology (Joe and Montgomery 2003). When the banking sector make profits, it not only contributes to the economic growth and stability but also enables the larger economy to withstand the negative external financial shocks (Athanasoglou, Brissimis et al. 2008). Therefore, the new dynamics have gradually put a lot of pressure on the managers and the entire banking fraternity to devise mechanism in order to become productive and increase performance of the entities they manage. In addition, competition has exerted a lot of pressure on the industry whereby firms must remain competitive to survive, through innovation development (Noyer 2007).

Kenya is esteemed as a regional hub for financial services and thus the vision foresees Kenya as a Regional Financial Center (RFC) in the entire East African Region. The Kenya's blue print, Kenya Vision 2030, emphasizes on strategic role of the sectors within the economy. More importantly, it places keen and thorough emphasis on the relevance of the financial societies towards stimulating the economic growth and achieve the larger economic goals both in terms of macro and micro economic factors. This is pertinent for the future growth forecasts and development of the country if it builds up on its strengths and maintains its competitive edge as a destination for the financial services both in the East and South African regions. In efforts towards improving efficiency and convenience in the financial sector, a lot of innovations have been developed in Kenya for both processes, products and services.

\subsection{The Financial System and Innovations in Kenya}

Kenya has high prospects of growth where the forecasted GDP growth rate was estimated at 6.5 in the year 2019 (World Bank 2018). In order for this growth to be achieved, all the sector of the economy needed to work in harmony. The financial sector is among the large sectors within the Kenyan economy whose players comprise the Central Bank of Kenya which regulates the financial sector, Commercial banks, cooperative Societies, Nairobi stock exchange (NSE), insurance companies, capital markets as well as non-bank financial institutions. In every economic cycle, the financial sector play a key role and acts as the inter-mediator between savers and borrowers. (Mishra 2008) elaborate that the financial sector innovation relates to creating and making popular innovative financial instruments and financial institutions, markets and technologies.

Currently forty-four different commercial banks exist in the financial sector in Kenya offering a wide range of financial services, one hundred and thirty foreign exchange bureaus, about forty major microfinance institutions (MFIs) (Gikandi and Bloor 2010). However, out of all the commercial banks, only twelve are listed at the stock market.

A classification done by Cherotich, Sang et al. (2015) group financial innovations into novel products, like the exchange-traded index funds and adjustable rate mortgage; emerging "production" processes like the electronically storing the record for securities and credit scoring; novel services like the organizational forms, Internet banking and on-line securities trading, examples being emerging exchange in electronic type for securities trading and Internet-only banks. Innovations are prevalent in the Kenya's financial sector and predominantly at the commercial banks. The banking and payments systems in Kenya's are relatively in the process of development compared to others within the larger East African region. Some evidence may include the implementation of real time gross settlement system (RTGS) commonly used for huge transactions since July 2005 with the aim of modernizing the payment mechanisms of the country and in conformity to the international trends.

Other systems include Magnetic Ink Character Recognition (MICR) for speedy and efficient cheques clearance; automated clearing house, Pesapoint services, extensive bank branch networks, mobile payments innovations like M-pesa, ZAP and Essar, and mobile money (MM) transfers systems which are at an upward growth trajectory (Omwami and Omwami 2010). These innovations do not only allow for the access of the services but also yield better customer satisfaction. A major innovation which was witnessed recently was the investment in long term Government bonds (Securities), operated mainly through mobile banking and electronic money transfers particularly by M-Pesa and Zap services. Further, agency banking grew tremendously arising from the Kenya banking act amendment through the finance Act of 2009 and the licensing of few credit reference bureaus Mbiti and Weil (2015), as well as robust infrastructure of the internet connectivity, positive economic culture and access to mobile phones.

Generally, the financial innovations in Kenya are catalyzed by several factors including; technological advancements, globalization, the dynamic conditions within the economy, industry competition among industry players, shareholders' expectations of returns through profits generation, financial regulation and rising coherence 
between the international and domestic financial markets (Ho 2011). Further, over and above performance, the innovations have created a platform for financial inclusion for all services offered to market for all people indiscriminately and make the services more affordable, convenient, accessible and efficient. Innovations have brought services closer to the people where the population get to be empowered and facilitated to access services with ease and within reach. The culture of the society in Kenya is that of saving and spending and therefore, with a defined system of saving and lending, coupled with efficiency and effectiveness, may result to different successes in the firm's performance.

Kenya's economy is vibrant with a population of 47 million people and has big prospects for further growth. In order to provide a wider reach of the population in provision of financial services, the financial firms have been investing in innovations so as to make their services accessible, affordable and competitive. However, due to the high cost of investment required to set up a bank branch in every location and make profit, the traditional banking industry has not been able to reach every corner of the society in providing their service. Thus, due to the huge population compared to available distribution network of the bank branches, the clients always get caught up by the long queues in the banking halls. In exploration of this opportunity, M-Pesa and agency banks have been developed in provision of convenient and effective services using of mobile phones at any location. M-Pesa provide a platform for money using the mobile phone. This innovation platform was launched in 2007 and has served to be the largest mobile network operator for both the markets in Kenya and Tanzania (AFI, 2010). M-pesa has been recognized and regarded as a great innovation in money transfer in the country.

During inception, M-Pesa had 175,000 customers and 577 agents by July 2007, but has grown to over 11.83 million customers and 23,000 agents as of July 2018 (Rajapathirana and Hui 2018). Despite the market challenges, M-Pesa potentially battled the storm and is currently a leading payment system in the country (Mwangi and Sichei 2011). Predominantly, the mobile Internet facilitate consumers purchases from any location and at any time (Linck, Pousttchi et al. 2006). In Kenya, traditional financial system has not met the societal demands adequately for providing access to banking services for the larger or entire population, with only a limited outreach (Abdelkafi, Makhotin et al. 2013). For example, the larger number of people in the marginalized societies living away from the big cities do not access banking services due to either lack of banking services as well as lack conservativeness and lack of knowledge on the benefits of opening bank accounts and saving money through the banks. According to Fin Access, (2016), only twenty-three percent of Kenyans above the age of eighteen years have access to formal finance such as banks, with twenty-seven percent of them in informal banking. Further, thirty-eight percent of the population doesn't seem to be aware of banking. In addition, $33 \%$ is totally excluded from the services in the financial sector.

Generally, access to finance in Kenya remains limited to the main cities (Beck and Fuchs 2004). As a way towards ensuring reasonable financial inclusion, (Brooking and Singer 2016), highlight that technological innovations like agency banking and M-Pesa have facilitated financial services greatly to the Kenya inhabitants at a lower cost. Arising from this scenario, most financial firms including banks have embarked on an extensive and aggressive innovation program which has seen these institutions develop different innovations to improve on their customer services as well as become efficient in their processes. It is therefore pertinent to evaluate the mechanisms existing between process innovation and their ultimate effect on financial performance on the banks from a different perspective especially in a developing economy with emerging markets like Kenya.

This paper evaluated the following questions and issues through the empirical analysis and research: a) Do process innovations influence the performance of firms positively or negatively? b) To what extent do these innovations affect the industry's performance and influence its equilibrium state? c) Does process innovation enhance industrial interaction or barely supports industry differentiation? Further, the paper provided a locus for making pertinent decisions on the effect of process related innovations on the Kenya's commercial banks financial performance and associated research in emerging markets for developing economies. To the best of our knowledge, though several studies had been undertaken on innovations, the assessment of the process innovations in an emerging market like Kenya had not been evaluated thus, necessitating the importance of the study.

\subsection{Data}

Various sources were combined to provide firm level data that was used in this paper. The World Bank Enterprises Surveys (WBES), Communication authority of Kenya and Safaricom Limited's websites provided firm-level data. The Central bank of Kenya (CBK) and the Kenya National bureau of statistics provided additional supplementary data on the performance at the firm level, being the banks regulator as well as the custodian of governments data in Kenya respectively. WBES provided information on factors that indicated constraints in the firm's performance and the business environment and at the same time provide pertinent direction in the economic development of a country. The study considered all commercial banks in Kenya and utilized firm level data on the surveys conducted from 2014 to 2018 after innovations adoption and from 2009 to 2013 before all the innovations were adopted to assess for the effect of innovation on performance. In investigating how process innovations affect financial performance of the banking industry in Kenya, recent database was payed attention to, towards developing 
measures for improvement and boosting productivity.

The rest of the paper is arranged in to different parts as follows: part 2 focuses on the literature review and hypothesis development, part 3 on the methodology, part 4 looks at the results, part 5 looks at discussions, while part 6 looks at the conclusion.

\section{Literature review and Hypothesis Development}

Industrial development and innovation is a key to economic development and competitiveness (Akman and Yilmaz 2008). Thus, organizations need to focus on innovations in their processes, service provision and production, in order for them to remain competitive and provide better services to their customers as well as remain efficient in their service provision. The need for innovation has been highlighted by authors from time to time. While the innovations on the products are implemented to react to the changing demands in the market, the technological advancements take advantage of this phenomenon and new innovations are developed. A classic example was the mobile money (MM) transfer services; a platform which was widely recognized and preferred as a payment system in Kenya Beck and Fuchs (2004), internet banking; and agency banks, which were regarded as direct indicators of Financial Innovation (Misati, Njoroge et al. 2010).

\subsection{Mobile banking and Innovation}

Mobile banking is the use of a cellular device or a mobile phone to execute an online transaction tasks, some of which are: monitoring of balances in the account, transfer of money between accounts and payments of bills (Arvis, Ojala et al. 2018). The innovation through mobile banking can be discussed using Innovation Diffusion Theory (IDT). This theory was first defined and employed by (Sahin 2006), as a good tool for understanding what technology is, as well as harmonizing the importance of technology and its role in other organization structures. Technological innovation is demanded by the need to offer services better and competitiveness. This process of dynamic technological development and innovation was emphasized in Adner and Levinthal (2001), through an explanation on the way demand environment and the development of technology relate using heterogeneous threshold. (Lawson and Samson 2001)highlight that the relationship between mobile payment technology innovation and the way in which the financial industry has evolved is significantly positive. The four elements of diffusion that affect the adoption of innovation are; communication channels, time and social systems. Noyer (2007) further highlight that an individual's perception on the relative advantage, innovation observability, trialability, compatibility and social norms affect his technological adoption behavior. This would therefore mean that peoples' willingness to adopt innovations especially on the banking industry like mobile banking as compared to cash is highly dependent on his willingness and the social norms. Much literature on electronic money and banking ignores mobile banking and further equates mobile money with currency substitution mechanisms such as virtual currency and smart cards. Mobile banking is simply using mobile phone devices to undertake a financial transaction. However, effects of mobile banking have either not been given keen attention or are simply ignored. This therefore triggered a fresh focus on the evaluation of how mobile banking affect performance of firms. In addition, innovation like mobile banking acts as a means for industrial and economic benefits to companies and provides an avenue for inducement for incremental return mechanisms (Hall 2004).

To some extent, innovation results to promotion in industrial synergy and industrial differentiation in others. Solow (1957), further insist that innovation is a pertinent element in ensuring the long-term country's development, competitive advantage and growth. Mobile banking is an extension of the modernizations that leads to benefits and advantages arising from Information Technology. Bharadwaj, Sambamurthy et al. (1999) emphasize the need for innovation where they point out that it gives the firm the ability and creates room for developing systems that are cost effective and can be relied upon by the business. Further, it facilitates integration of business strategy, and anticipate business needs ahead of competitors. Akman and Yilmaz (2008) posit the importance of the innovation elements like mobile banking innovations that possess skills to solve technical and business issues.

According to Faber and Hesen (2004), innovation directly determine the firm's ability to rapidly develop and execute critical systems for competitive advantage in future. Kearns and Lederer (2001) conclude that the extent to which the innovation reflects the business plan is a significant antecedent to competitive advantage. However, the process of motivating and nurturing it is extremely demanding. Similarly, in Holmstrom (1989), the process of innovation is not only long, eccentric and unpredictable but also bears huge risk of failure. The establishment and adoption of mobile banking as an innovation especially in an economic environment like for Kenya is an expensive activity and is perceived to have resulted to success in some cases to some extent and little or no success in others. This therefore leads us to the development of the first hypothesis:

Hypothesis 1: Mobile banking has no effect on the financial performance of the firm

\subsection{Agency banking and Innovation}

An agent bank is defined as a bank that operates in place of another individual bank, a group of banks, a company or an individual (Kapur, Lewis et al. 2011). Agency Banking involves the provision of controlled and limited 
banking and financial services to the society through agents who may have been engaged under a valid agency agreement, as compared to a teller or a cashier (World Bank 2011). The agent banks are globally being utilized and classified as crucial distribution channels towards financial inclusion, (World Bank 2010). World Bank (2009) further indicate that the estimated population worldwide that does not have a basic account is 2 billion adults. In order to bridge this gap, Governments across the world have been directing their focus on implementation of financial inclusion policies to get rid of poverty, provide access to all people and ultimately stabilize the economies. However, based on the statistics from World Bank (2009), about 59\% of adults with no bank accounts cite the lack of affordable and accessible banking services as reason for this cause. Further, the unavailability of banking services in remote areas and the lengthy documentation procedures were also cited as additional reasons for lack of bank accounts. However, in the high-end economies, banks provide their services through bank branches and ATMs but this is a challenge to them due to lack of breaking even.

This has been the reason attributed to why many banks do not concentrate on reaching out on the rural customers. It was for this reason that banks in Kenya partnered with experts in technology innovation in different banks to launch networks for agent banking to facilitate the banking services to places where a bank branch could not reach (World Bank 2009). Aduda and Kingoo (2012) highlight the benefits of agency banking as; "providing banking services to a huge group of customers at reasonably reduced fee, simplification of business transactions for efficient service delivery, promotion of cashless culture and promotion of multiple products and facilities by use of one agent; and ease of reach by many customers".

In Kenya, banks resulted to adoption of agency banking towards offering services to the unbanked at a cheaper rate through training of agents who sign agreements to undertake it on their behalf. Some giant economies in the world have also appreciated and implemented the agency banking like Latin America and Asia, while only a few African countries have taken up this process innovation. Though technology provides a platform for facilitating industrial metamorphosis and diversification, leading to market competition (Agarwal and Prasad 1997) it does not give a guarantee for ultimate breakthrough. (King and Levine 1993), argue that technology is critical in nurturing process innovations and forms a platform for market participants to diversify their risk. Few studies have been done to evaluate the value added by agency banking system on the banks performance, some of which have indicated positive results.

For example, in a study on the impact of ATMs and agency banks on market share for deposit in branch banking operations, Liu, Kauffman et al. (2015) found out a certainly correlated effect with a market share for branches of demand deposits which were local. Further, positive result were established in estimating savings deposit market shares (Ayalew and Xianzhi 2019). Wachira and Ondigo (2016) further show positive results on the use of agency banking facilities for bank performance improvement, through customized products, expanded range of products, increased market share and better client demand response. Previous studies indicate a positive results with both intention of adoption of innovation (Davis, 1989) and innovation continuance (Moghavvemi, Hakimian et al. 2012)

In a study by Ayalew and Xianzhi (2019) towards evaluating the inference of banking competition towards ease of credit access by firm's Africa, modernization of systems in banks may assist in the costs reduction and minimization of procedural complexities. Thus, the process of modernizing infrastructure for information technology may be a pertinent strategy towards modernizing institution in the banking division. The traditional banking industry has over time dwelt on the banking hall model to serve its customers. However, with the advancement of technology, banks have since moved a step further towards establishment of the agency banking system whereby, customers can access their accounts and either deposit or withdraw money without having to visit the banking hall. This development has proved to be convenient and time saving. However, Yi-Ching Chen and Yeh-Yun Lin (2007) noted that the conservative financial institutions may not have the capacity to fulfill theses needs. The criticism by, Dishaw and Strong (1999) and Venkatesh and Davis (2000) against the complements by Kimingi (2010) led the attention to assess the influence of agency banking system on the increase or decrease of banks profitability especially in the Kenyan context. This led to the development of our second hypothesis:

Hypothesis 2: Innovation through agency banking services has no effect on the firm's Financial performance.

\subsection{Internet based banking services and Financial performance}

Banking through the internet also generally known as online banking is a new innovation which banks have resulted to improve their efficiency. Cherotich, Sang et al. (2015) define internet Banking or electronic banking as a large field of systems and solutions whereby the transactions are accessed through public or private networks using the internet. It is simply virtual banking. Through internet banking, one is able to access his accounts with ease, receive spot information on financial products, conduct financial transactions and services and track his financial transactions through the internet without visiting a bank teller. Athanasoglou, Brissimis et al. (2008) conclude that emerging information technologies, brought about by the Internet, have greatly transformed modern commercial activities. Ecommerce has eased transactions by providing easy access of services, wider global reach and a round the clock availability, (Abdelkafi, Makhotin et al. 2013), coupled with the internet of things (IoT) and 
cloud computing, which have conveniently and efficiently made logistics easier (Brissimis et al. (2008). Ling Guo, Qu et al. (2017) highlight that internet-based technology and mobile services technology facilitate convenience and moderates both upstream and downstream markets in comparison to conservative banks.

Mostly, in the traditional banking industry, the banks provide the services to their customers in a queueing system and in a banking hall. Through globalization and interconnectivity, the banks have adopted this technology and provide services to the customers conveniently at any location around the world as long as there is connectivity. This can further be discussed using the Schumpeter theory of innovation. Based on Ling Guo, Qu et al. (2017), through innovation, entrepreneurs develop, create, nurture and maintain opportunities for new returns. In fact, banks act as the managers of the function of providing liquidity during the provision of a payments services and system. Further, banks and depository institutions provide their customers with a pool of liquidity where they insure and shield them against shocks for liquidity (Diamond and Dybvig 1983). The internet banking provides timely and valuable information to the customers at a lower cost of information. Though the benefits of internet banking are immense, there are also risks associated with the convenience, some of them being security risks as a result of disintermediation of data (Adegbaju and Olokoyo 2008). Some studies have interrogated the effect of technology on bank risks. For example, in a study to evaluate the financial innovations effects on commercial banks' risk management in Kenya Waweru and Spraakman (2012) conclude that savings accounts, trading system which are automated at the stock exchange, credit reference bureaus and current accounts were positively correlated to the entire commercial banks' risk management framework.

In addition, internet banking is posed with the challenge of societal expansion rising from a small population to a multitude of people accessing the data from the internet (Soludo 2005). Further, Waweru and Spraakman (2012) found out that internet banking was negatively correlated with risk management framework and conclude that financial innovations have led to commercial banks in Kenya be exposed to various risks including country risk, credit risk, interest rate risks, compliance risk, liquidity risk, strategic risk, and reputational risk all which form part of the overall institutional risk management framework through an index factor which was realistic. In assessing the impacts of ICT on banks performance, Kimingi (2010) found positive results and further highlight that banks with high financial performance were those which incorporated ICT in their activities. Similarly, Leitch and Davenport (2003) conclude that investment and use of ICT also require investment in skills, innovation organization and careful management of the prevailing risks and costs which may reduce profitability.

The establishment of internet banking through transfers of RTGS and electronic funds transfers (EFTs) is a great innovation on the banks as a product that enhance both convenience and efficiency (German, Schoneveld et al. 2013) though its implementation requires great resources. Cherotich, Sang et al. (2015) further emphasize that implementation of financial innovation is a great investment for banks but require enormous resources. More evidence has been provided by Bharadwaj, Sambamurthy et al. (1999) on how bank performance has improved through use of e-banking. Some of the areas pointed out were; customized products, expanded product range, increased market share, and improved responses to the needs for the clients. Therefore, based on the literature, the effect of internet banking services in the banking industry's performance may not be ascertained to be positive or negative, but it can be evaluated for certainty. This led to the development of the third hypothesis:

Hypothesis 3: Innovation through Internet based banking services has a negative influence on the financial performance.

\subsection{Firm Performance}

The performance of the firm is assessed through returns and is the ultimate objective of its setup and existence. Performance has been flagged out by Santos and Brito (2009) as a crucial concept for business strategy. Previous studies highlight a positive relationship between innovation and performance of the firms by evaluating different variables. Close links have been drawn between innovation and firm's performance, (Volberda, Van Den Bosch et al. 2013). Most of these studies evaluate effects of innovation as either a technological advancement or as an output for firm's capability and performance (Camisón and Villar-López 2014). Different indicators have been defined as best suited for measurement of firm's financial performance. For example, Sohn and Jung (2010); Aghion, Harris et al. (2001) highlight that production, finance or marketing indicators relate to firm's growth and profits, though the measurement may sometimes be either subjective or objective.

This study aimed to evaluate the effect that process innovations display on firm's financial performance and thus, financial profitability indicators i.e. Return on Assets (ROA) was considered as the measure for performance in line with Aduda and Kingoo (2012); Aghion, Harris et al. (2001). However, many of the firms, adopt the use of financial indicators both financial and accounting to measure their performance. According to Tavitiyaman, Qiu Zhang et al. (2012), examples of these indicators include; Return on Equity, net profit after tax, return on investment (ROI), Return on assets (ROA) and average annual occupancy rate. Further, Bagorogoza and de Waal (2010) highlight that market share, growth, profitability, satisfaction of stakeholder, productivity, and competitive position are other measures that could be used to evaluate firm's performance. The measures for financial performance indicate how best firms generate expected value for their owners (Wald 1999) 
Most commercial banks use innovation to enable them compete and ultimately boost their performance towards maintaining their effectiveness in the market (Bátiz-Lazo and Woldesenbet 2006). Different scholars have studied the relationship between innovation in technology and firm performance using different variables and measures and thus achieving varying results. For example, Lööf and Heshmati (2006) in studying the effect that innovations had on performance highlight that concentration moved to the advanced process and channels of innovation whereby inputs innovation were synthesized and transformed for improved performance. Further, Grundiche (2004) emphasize that in developing products and product lines to satisfy the constantly emerging and changing needs of the market, firms require to innovate.

Further, to evaluate the effects that technological innovations had on the financial performance of commercial banks in Kenya Kimingi (2010) conclude that innovations related to technology resulted to enhanced performance. In addition, the study recommended firms to devise more mechanisms and be highly competitive. Similarly, banks should employ modem innovations in technological like internet-based banking services. Santos and Brito (2009) also highlight that firm's performance was in most cases evaluated using financial measures and thus, firms needed to focus their energy on satisfying and fulfilling the utility of their stakeholders. For purposes of this study, the ROA of the firms was used, in line with Aduda and Kingoo (2012) to evaluate the commercial banks in Kenya's financial performance as a result of their resultant effect from the innovation capabilities. Although process innovation seemed to influence positively the financial performance of the innovators, it was pertinent to understand financial performance effects on Kenya's commercial banks arising from the dynamics presented by the need for change from time to time. It is against this background that this paper analyzed the effects of process innovations on financial performance of the banking industry focusing on the Kenya's commercial banks and where the findings were positive. The findings of this study would assist the policy makers in defining mechanisms for suitable strategies for innovations in the banking sector. Findings could further benefit the policy makers in increasing their firm's competitiveness and ensuring conducive environment for innovation and practices are in place (Chen, Huang et al. 2010).

\subsection{Innovation for the Research}

Previous studies highlight a positive and direct relationship between innovation and performance of the firms. Some studies considered the whole cycle of E-commerce while evaluating the effects of technology on performance. However, this study, being a buildup of other related studies done previously distinguishes between the internet banking, agency banking and mobile banking which are considered as key components for process innovation. This study also controlled some variables like the firm size and leverage to develop a model and evaluated the effects of all the variables on firm's financial performance. Further, to evaluate the performance of the firm, the author considered return on assets (ROA) in line with Aduda and Kingoo (2012), and further compared the performance of the firms before innovations adoption with the performance after the innovation adoption to evaluate their performance during the two periods for five years with 2014 as the base year.

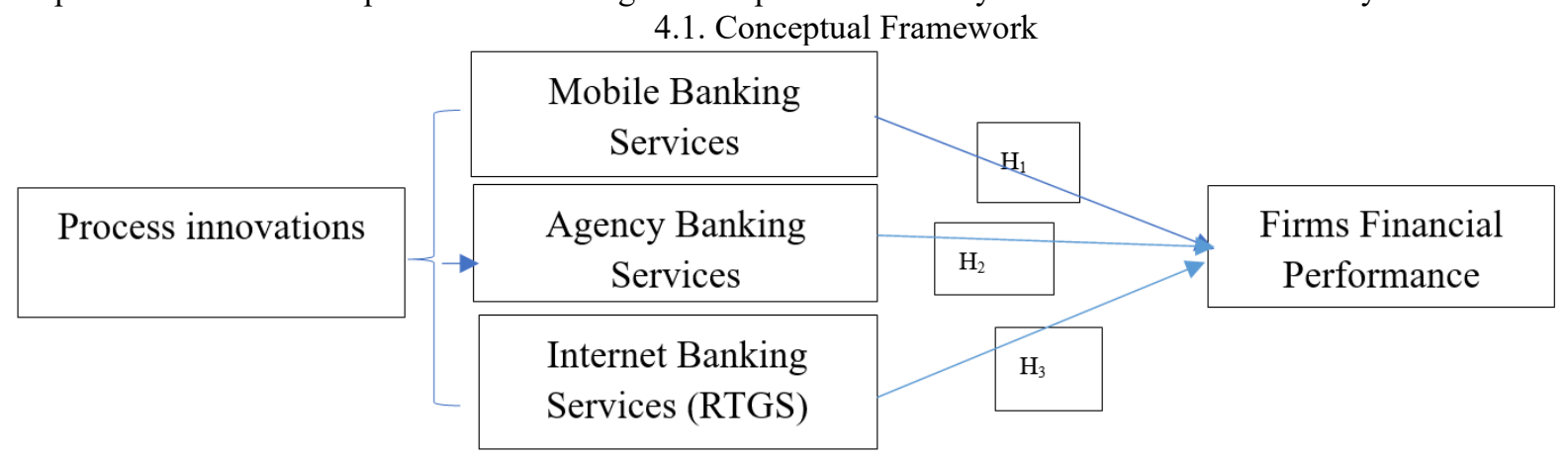

Figure 1. Conceptual Framework. (Source: Author, 2019)

According to figure 1, mobile banking services, agency banking services and internet banking services represented the components considered key in process innovation as the independent variable while firm performance was the dependent variable.

\section{The Methodology}

For purposes of this study, causality approach was most preferred because it was investigative and focused on whether process innovation as adopted by the banks led to increase or decrease in bank performance. The descriptive research design was applied. First, the study evaluated the performance before innovation to assess the trend. Further, the study evaluated the trend of bank performance after the adoption and use of process innovation in Kenya's banking sector. The explanatory approach was used examine the relationship between process innovation and bank performance, while the causal objective for the research of the study was tested (Chandran 
2004).

This study considered the process innovation measures for the banks and their effect on financial performance for two different periods i.e. five years after innovation period (2014-2018) with 2014 as the base year when all the innovation variables for the study were fully adopted, got the average for the financial performance measure (ROA) for 5 years of pre-innovation period before 2014 (i.e. 2009 to 2013), compared the results and evaluated the firms' financial performance during the two periods to assess for any change.

\subsection{Proxies for control variables}

Several studies carried out previously have assessed and highlighted different factor that affect the firms based on their distribution networks and assets base. Also, some studies found out that large firms faced a high risk of litigation in comparison to smaller ones (Lys and Watts 1994). This therefore explain the justification to include the size of the firm as part of the control variables computed as the natural logarithm of the firm's overall total assets in line with Lepetit, Nys et al. (2008) within a year. In addition, banks depend mostly on interests from loans and deposits as the main sources for their returns. Therefore, any factor affecting these sources ultimately affect the return and performance. Benkel, Mather et al. (2006) highlight that the increased chances for defaulting the debt relates to earnings management. For this reason, leverage also formed part of the factors to be controlled and was computed as the ratio between the firm's $I$ total debt to total assets in year $j$.

\subsection{Sample of Research}

According Kim and Han (2000), a population is the wholesome element's collection for making inferences by the researcher. The total population of attention in this study was all 44 commercial banks operating in Kenya. However, due to lack of information on innovation during the data evaluation, some banks were dropped, thus remaining with 27 commercial banks which is equivalent to $63 \%$ of the target population.

Table 1: Description of the Variables and their measurements

\begin{tabular}{|c|c|c|c|c|}
\hline $\begin{array}{l}\text { Variable } \\
\text { description }\end{array}$ & Variable & Symbol & $\begin{array}{l}\text { Expected } \\
\text { Sign }\end{array}$ & Measurement \\
\hline $\begin{array}{l}\text { Dependent } \\
\text { Variable }\end{array}$ & $\begin{array}{l}\text { Financial } \\
\text { Performance }\end{array}$ & FPERF $_{i j}$ & & $\begin{array}{l}\text { ROA (ratio of its net income in period t to the total } \\
\text { value of } \\
\text { assets) }\end{array}$ \\
\hline \multirow[t]{3}{*}{$\begin{array}{l}\text { Independent } \\
\text { variables }\end{array}$} & $\begin{array}{l}\text { Mobile banking } \\
\text { services }\end{array}$ & $\mathrm{MOB}_{i j}$ & $(-)$ & $\begin{array}{l}\text { Bank transactions through the Mobile banking } \\
\text { services during the period in Kenya shillings (Kshs) }\end{array}$ \\
\hline & $\begin{array}{l}\text { Agency banking } \\
\text { services }\end{array}$ & $\operatorname{AGEN}_{i j}$ & $(-)$ & $\begin{array}{l}\text { Bank transactions through the agency banking } \\
\text { services during the period in Kshs }\end{array}$ \\
\hline & $\begin{array}{l}\text { Internet basec } \\
\text { banking services }\end{array}$ & $\mathrm{INT}_{i j}$ & $(-)$ & $\begin{array}{l}\text { Bank transactions through the Internet platform } \\
\text { during the period in Kshs }\end{array}$ \\
\hline \multirow{2}{*}{$\begin{array}{l}\text { Control } \\
\text { variables }\end{array}$} & Firm Size & $\operatorname{Size}_{i j}$ & & Logarithm of total assets for a firm \\
\hline & Leverage & $\operatorname{Lev}_{i j}$ & & Ratio of total debt to total assets of firm \\
\hline
\end{tabular}

The table 1 describe the variables and their measurements where firm performance was measured by ROA (ratio of its net income in period $t$ to the total value of assets), mobile banking services measured by bank transactions through the mobile banking services during the period, agency banking services measured by bank transactions through the agency banking services during the period, internet banking services measured by bank transactions through the internet platform during the period, all controlled by firm size as measured by the logarithm of total assets for a firm and leverage as measured by the ratio of total debt to total assets of firm.

\section{Results}

4.1 Descriptive statistics

The total population for the study included all the commercial banks that implemented the process innovations in Kenya and have made public their data on innovation. We drew a sample from 44 commercial banks but only analyzed 27 commercial banks which provided data for innovations. The data include mobile banking transactions, agency banking transactions and internet banking transactions. Table 2 below shows the descriptive statistics about the data. 


\begin{tabular}{|c|c|c|c|c|c|}
\hline & Observations & Mean & $\begin{array}{l}\text { Std. } \\
\text { Deviation }\end{array}$ & Minimum & Maximum \\
\hline MOB & 274 & 13.28 & 11.582 & 15.009 & 22.334 \\
\hline AGEN & 274 & 15.45 & 7.348 & 13.320 & 18.623 \\
\hline INT & 274 & 14.48 & 8.503 & 11.334 & 17.008 \\
\hline SIZE & 274 & 11.41 & 2.193 & 8.870 & 11.222 \\
\hline LEV & 274 & 13.84 & 7.484 & 10.232 & 17.243 \\
\hline
\end{tabular}

This table summarized descriptive statistics of the study variables. MOB was transactions through mobile banking, AGEN was transactions through agency banking; and INT was transaction through internet banking. LEV and SIZE were control variables.

As shown in Table 2, a total of 274 observations were made. The minimum value of process innovation on banks for mobile banking was 15.009, the maximum value was 22.334 marks, and the average value was about 13.28. The minimum value for agency banking was 13 , the maximum value was 18.6 marks, and the average value was about 15.45. Finally, internet banking had a minimum value of 11 and a maximum value of 17, giving 14.48 as the average and 8.5 as the standard deviation. Based on the results, agency banking contributes greatly to the performance of the commercial banks in Kenya with a mean of 15.45 .

\subsection{Correlation and regression model}

To test the individual impact of each independent variable on firm's financial performance the authors decided to use Pearson correlation, as a univariate test. On the other hand, the study considered the following multiple regression model, as a multivariate test to analyze and establish the nature of the relationship for both the dependent and the independent variables and further examine the joint effect of the dependent variables i.e. mobile banking, agency banking and internet banking as process innovations considered by the study controlled by size of the firm, and leverage on banks financial performance.

\section{Model equation:}

$$
\text { FPERF }_{i j}=\beta_{0}+\beta_{1} \text { MOB }_{i j}+\beta_{2} A_{G E N}+\beta_{3 j} I N T s_{i j}+\beta_{6} \text {SIZE }_{i j}+\beta_{7} L_{E V} V_{i j}+\mathcal{E}
$$

Where FPERF $_{i j}$ represented Financial Performance for firm $\mathrm{i}$ in year $\mathrm{j}$, as measured by Return on Assets (ROA); $\mathrm{MOB}_{i j}$ represented mobile banking services for firm $\mathrm{i}$ in year $\mathrm{j}, \mathrm{AGEN}_{i j}$ represented agency banking services for firm $\mathrm{i}$ in year $\mathrm{j}$. $\mathrm{INT}_{i j}$ represented internet based banking services for firm $\mathrm{i}$ in year $\mathrm{j}$ as measured by RTGS transfers from year $1 \ldots \mathrm{n}), \beta 0$ represented a Constant value, $\beta_{1}, \beta_{2}, \beta_{3}, \beta_{4}, \beta_{5} \beta_{6} \beta_{7}$ and $\beta_{8}$ represented Parameters to be estimated, Size $i j$ represented the logarithm of total assets for a firm in a fiscal year, Lev $i j$ represented the ratio of total debt of firm $I$ for year $j$ to total assets of firm $I$ for year $j$ and $\varepsilon$ represented the error term.

The impact of any independent variable (process mobile banking, agency banking and internet banking) on the performance of the firms was captured by its coefficient, $\beta$. A significantly negative (positive) value of $\beta$ revealed that the related independent variable with that $\beta$ decreased (increased) firm's performance, which meant that this factor was negatively (positively) associated with the performance of the firms.

4.3. Bank's Financial performance (ROE) before the Innovations (2009-2013)

This study aimed to evaluate the effect of process innovations on the Kenyan commercial banks. The study further evaluated the performance of the banks for two periods i.e. before the innovations and after the implementation of the identified elements of process innovations. Therefore, two periods were considered for this study i.e. before innovations (2009-2014) and after innovation (2014-2018), to assess the effect that these innovations have on the performance of banks as measured by (ROA). Table 3 shows the consolidated average ROA for the sampled population before innovation for the period 2009 to 2013.

Table 3: Bank's Financial performance (ROE) (2009-2013)

\begin{tabular}{|l|l|l|l|l|l|}
\hline Year & $\mathbf{2 0 0 9}$ & $\mathbf{2 0 1 0}$ & $\mathbf{2 0 1 1}$ & $\mathbf{2 0 1 2}$ & $\mathbf{2 0 1 3}$ \\
\hline Consolidated average (ROA) & 0.019 & 0.023 & 0.021 & 0.027 & 0.024 \\
\hline
\end{tabular}

In order to get the ROA, the total assets were taken as a ratio with the net profit after tax during the preinnovation period. Based on the data, ROA for commercial banks slightly increased from 0.019 in 2009 to 0.023 in 2010 , decreased slightly to 0.021 , increased slightly to 0.027 in 2012 and later dropped to 0.024 in 2013 as indicated in the graph below. 


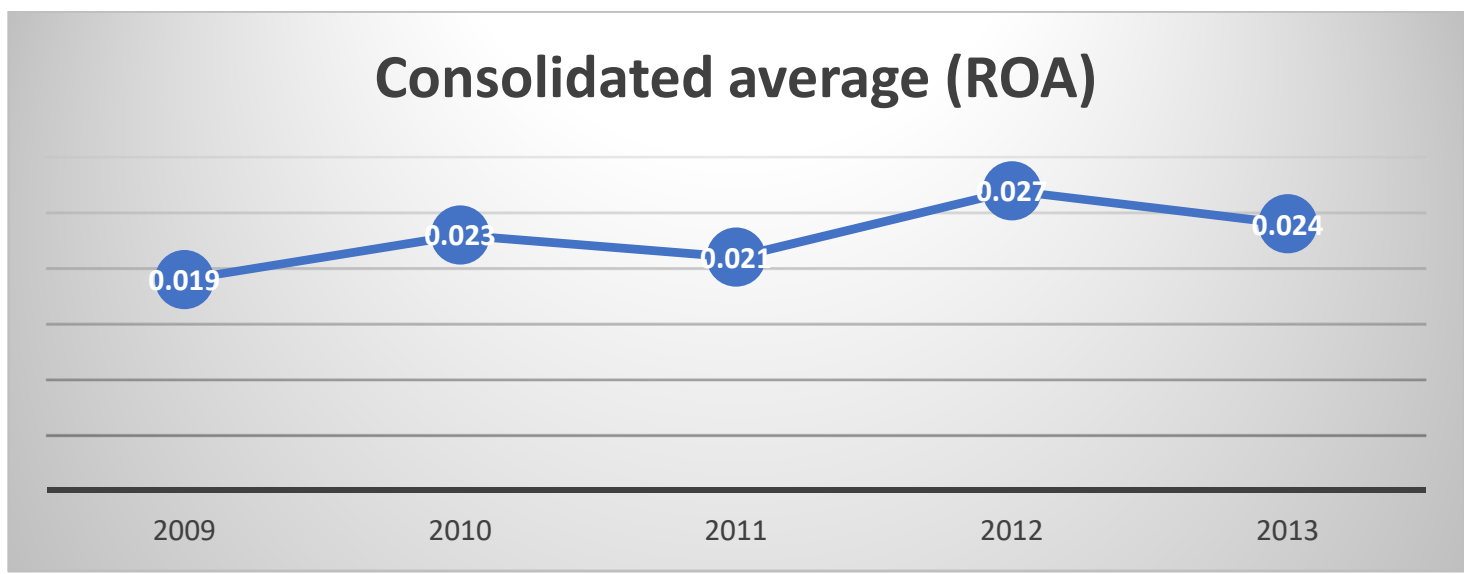

Figure 2. Consolidated ROE for the period 2009 to 2013

Based on figure 2 above, the return on assets for the banks was increasing gradually at a slightly increasing rate from the year 2009 to 2010, later dropping in the year 2011, further gradually increasing in the year 2012 and ultimately dropping in the year 2013. The slight increase may have resulted from revaluations of assets and not real profits during the pre-innovations period.

\subsection{Discussion}

Before discussing the results, several assumptions related on the classical linear regression model were critical to be tested. These include: tests for homoscedasticity for the error terms, tests for lack of perfect multicollinearity on the independent variables, tests for assumption of normality on the error terms, and finally tests for lack of existence for autocorrelation between the error terms. The results for the examination of the tests for these assumptions indicated a validity for the interpretation of the regression estimates. Further, this paper elaborated the expected results of multiple regression analysis correlation matrix (univariate test) and (multivariate test).

\subsection{Univariate test (correlation matrix)}

Table 4 below show the evaluation of variables using the Pearson correlation analysis. Based on the results, mobile banking, internet banking, and agency banking showed substantial results to banks performance in Kenya and were therefore critical in the explanation of the firms' performance as measured by the Return on Assets (ROA).

Table 4: Analysis based on Pearson correlation coefficient

\begin{tabular}{lllllll}
\hline & FPERF & \multicolumn{1}{c}{ MOB } & AGEN & INT & SIZE & LEV \\
\hline FPERF & 1 & & & & & \\
MOB & $0.486^{* *}$ & 1 & & & & \\
AGEN & $0.678^{* * *}$ & $0.448^{* * *}$ & 1 & & & \\
INT & $0.353^{* *}$ & 0.0884 & 0.146 & 1 & & \\
SIZE & 0.0478 & 0.0092 & $0.0686^{* *}$ & 0.2864 & 1 & \\
LEV & 0.0240 & 0.0040 & 0.0260 & 0.0032 & 0.0081 & 1 \\
\hline
\end{tabular}

Table 3 above indicate the analysis for the Pearson correlation coefficients on the relationship between the dependent and the independent variables. Based on the table, FPERF shows the performance of the firm as measured by the Return on Assets (ROA), MOB indicated the transactions through mobile banking, AGEN indicated the transactions through agency banking while INT indicated the transactions through internet banking. The $* *$, and $* * *$ showed $5 \%$ and $1 \%$ significance levels.

Based on the results from the correlation analysis, transactions through agency banking bests explained the financial performance of the banks in Kenya as measured by the Return on assets (ROA) with the highest coefficient of 0.678 , and a significant level at $1 \%$. Secondly, transactions through Mobile banking with a coefficient of 0.486 and a significant level of $1 \%$ explained the financial performance of the banks in Kenya. Thirdly, transactions through the Internet banking explained 0.353 of the bank performances significantly at $1 \%$. Further, based on the analysis, firm size and the leverage levels influenced the bank's financial performance. With a $1 \%$ significance level, size and the leverage had a positive coefficient of 0.047 and 0.024 respectively.

The coefficient which were positive in the analysis indicated that the above process innovations that the banks put in place contributed positively to the financial elements of performance and more and more of process innovations needed to be invested more on by the banks in order to boost their financial performance (ROA) and take advantage of the unexploited opportunities in the markets. 
5.2 Multivariate test (regression analysis)

Table 5 indicated the output for the multiple regression evaluation. The $\mathrm{R}^{2}$ of our regression model was $64.77 \%$. This could be explained that $64.77 \%$ of the variation in all the independent variables under consideration i.e. transactions through internet banking, agency banking and mobile banking explained the financial performance as an output and dependent variable for the commercial banks in Kenya. Further, the F-statistic's (0.0265) $p$ value was below $1 \%$. Therefore, we rejected the null hypothesis and conclude that that all independent variables collectively had a positive effect on the dependent variable collectively. Further, based on the $p$ values for each of the variable, all the $p$ values were below the level of significance of $1 \%$ hence, the null hypothesis is rejected and deduction made that mobile banking, internet banking and agency banking positively influenced firm's financial performance especially on the Kenya's commercial banks. The analysis of Variance showed that the value of Fcalculated (2.577) was higher than F - critical (0.228). This therefore indicated that the regression equation was well fitting to the variables and the coefficients showed a relationship which is positive between performance of banks and the elements of process innovation under consideration.

Table 5: Multivariate test and Regression analysis

\begin{tabular}{|c|c|c|c|c|}
\hline AIG & Expected sign & Coefficients. & t-statistic & $\begin{array}{l}\mathrm{p}- \\
\text { value }\end{array}$ \\
\hline MOB & + & $0.259^{* *}$ & 2.572 & 0.006 \\
\hline AGEN & + & $0.970 * * *$ & 10.065 & 0.000 \\
\hline INT & + & $0.519^{* *}$ & 6.746 & 0.000 \\
\hline SIZE & ? & $0.080^{*}$ & 0.010 & 0.008 \\
\hline LEV & ? & $0.052 *$ & 1.669 & 0.009 \\
\hline Constant & $?$ & $31.975^{* * *}$ & 3.519 & 0.001 \\
\hline Observations & 274.0000 & & & \\
\hline F-statistic & $2.6500 * * *$ & & & \\
\hline F-Calculated & 2.5772 & & & \\
\hline F-Critical & 0.2282 & & & \\
\hline R-squared & 0.6477 & & & \\
\hline
\end{tabular}

The results of our analysis showed that the transactions through mobile banking, agency banking and internet banking had an effect on the commercial banks financial performance in Kenya. The results were consistent with the results of the Pearson correlation analysis and the univariate test.

The analysis of the coefficients show that a unit increase in the Kenya's commercial banks in transactions through mobile banking would increase the firm's financial performance by 0.259 . Further, a unit increase of the agency banking transactions resulted to an improvement in financial performance by 0.97 units. Similarly, a unit increase on the internet banking transactions led to an increase on the financial performance of the firm by 0.519 while bank size and leverage influenced the performance by 0.080 and 0.052 units respectively. Therefore, banks which invested in innovation on their processes reaped the benefits with regard to their performance in line with the findings from Kariuki (2005) which found positive results and further established that banks with high financial performance are those that incorporated innovations and information communication (ICT) in their activities.

\subsection{Estimated Equation:}

Return on Assets $=31.975+0.259 *$ Mobile Banking transactions $+0.97 *$ Agency Banking transactions $+0.519 *$ Internet Banking transactions $+0.08 *$ size $+0.052 *$ Leverage $+\mathcal{E}$

\section{Conclusion}

This study evaluated the effects of process innovation on performance of the Kenya's commercial banks. To effectively carry out the evaluation, the study endeavored to answer questions on whether the effect of process innovations on firm's performance was positive or negative, the level at which the innovations influence the financial performance in the entire industry's and its equilibrium state and finally evaluate whether the elements of process innovation enhanced industrial interaction or barely supported industry differentiation.

Based on the result, after rejecting all the null hypothesis, the study concluded that the return on assets (ROA) which measures the financial performance was positively influenced by the improvement on the process innovations including the transactions through mobile banking, transactions internet banking and transactions through the agency banking services. This was in line with the calculated $p$ values. Further, the results indicated that the size of the firm and its leverage levels influence its financial performance. Hence, conclusions were deduced that the implementation of innovations positively influenced the performance of the commercial banks in Kenya and led to competitiveness and financial stability. The conclusions were similar to those of Safarzyńska and van den Bergh (2017) which found a positive relationship on the influence between technological and financial systems on financial stability. Further, this study provided a locus for making pertinent decisions about effect of process innovation on the financial performance of the banking industry in the Kenya commercial banks and 
associated research in emerging markets for developing economies. Further, based on the report from World Bank (2011) on the bank's accessibility, most adults with no bank accounts cited the lack of affordable and accessible banking services, unavailability of banking services in remote areas and the lengthy documentation procedures. Therefore, banks should invest more on innovations in their processes in order to assist in closing this gap of the population without the bank accounts as well as tap the markets that are not tapped by the traditional model of banking.

In general, process innovation made it possible for banks to increase their profitability and further enabled the banks expand to new markets, boost their returns, improve their services for the customers and ultimately become competitive in the market. Further research may be done to evaluate the effect of other forms of innovations (organization innovation, product innovation, and marketing innovation) on performance. In addition, researchers may evaluate other measures of finances and test their effect from innovation using the mediating and moderating variables like the ownership structures as well as financial distress and flexibility. Due to the vulnerability of the innovations through the internet on the bank's operations, banks also need to mobilize for stronger Government support on the online crime laws as well as invest on the firewalls to bar attacks from the cyber-crimes. The study was only limited to the commercial banks in Kenya but may be extended to other sectors within the Kenyan economy like the savings and credit cooperative societies (SACCOs), micro finances and other financial industry sectors like the Insurance, in order to assess the effects of innovation on their operations and performance.

\section{References}

Abdelkafi, N., et al. (2013). "Business model innovations for electric mobility—what can be learned from existing business model patterns?" International journal of innovation management 17(01): 1340003.

Adegbaju, A. and F. Olokoyo (2008). "Recapitalization and banks' performance: A case study of Nigerian banks." African Economic and Business Review 6(1).

Adner, R. and D. Levinthal (2001). "Demand heterogeneity and technology evolution: implications for product and process innovation." Management science 47(5): 611-628.

Aduda, J. and N. Kingoo (2012). "The relationship between electronic banking and financial performance among commercial banks in Kenya." Journal of Finance and investment Analysis 1(3): 99-118.

Agarwal, R. and J. Prasad (1997). "The role of innovation characteristics and perceived voluntariness in the acceptance of information technologies." Decision sciences 28(3): 557-582.

Aghion, P., et al. (2001). "Competition, imitation and growth with step-by-step innovation." The Review of Economic Studies 68(3): 467-492.

Akman, G. and C. Yilmaz (2008). "Innovative capability, innovation strategy and market orientation: an empirical analysis in Turkish software industry." International journal of innovation management 12(01): 69-111.

Alvaredo, F., et al. (2018). World inequality report 2018, Belknap Press.

Arvis, J.-F., et al. (2018). Connecting to Compete 2018: Trade Logistics in the Global Economy, World Bank.

Athanasoglou, P. P., et al. (2008). "Bank-specific, industry-specific and macroeconomic determinants of bank profitability." Journal of international financial Markets, Institutions and Money 18(2): 121-136.

Ayalew, M. M. and Z. Xianzhi (2019). "Bank Competition and Access to Finance: Evidence from African Countries." Journal of Industry, Competition and Trade 19(1): 155-184.

Bagorogoza, J. and A. de Waal (2010). "The role of knowledge management in creating and sustaining high performance organisations: The case of financial institutions in Uganda." World Journal of Entrepreneurship, Management and Sustainable Development 6(4): 307-324.

Bank, B. (2010). "Review of corporate social responsibility (CSR) initiatives in Banks (2008 \& 2009)." Bangladesh Bank.

Bank, W. (2009). Africa Development Indicators 2008/2009: From the World Bank Africa Database, World Bank Publications.

Bank, W. (2011). World development report 2012: Gender equality and development, World Bank Publications.

Bátiz-Lazo, B. and K. Woldesenbet (2006). "The dynamics of product and process innovations in UK banking." International Journal of Financial Services Management 1(4): 400-421.

Beck, T. and M. Fuchs (2004). Structural issues in the Kenyan financial system: Improving competition and access, The World Bank.

Benkel, M., et al. (2006). "The association between corporate governance and earnings management: The role of independent directors." Corporate Ownership \& Control 3(4): 65-75.

Bharadwaj, A., et al. (1999). "IT capabilities: theoretical perspectives and empirical operationalization." ICIS 1999 Proceedings: 35 .

Brooking, E. T. and P. Singer (2016). "War Goes Viral: How social media is being weaponized across the world." The Atlantic.

Camisón, C. and A. Villar-López (2014). "Organizational innovation as an enabler of technological innovation 
capabilities and firm performance." Journal of business research 67(1): 2891-2902.

Chandran, E. (2004). Research methods: A quantitative approach with illustrations from Christian ministries, Daystar University.

Chen, C.-J., et al. (2010). "Knowledge management and innovativeness: The role of organizational climate and structure." International Journal of Manpower 31(8): 848-870.

Cherotich, K. M., et al. (2015). "Financial innovations and performance of commercial banks in Kenya."

Dean, B. V. (1986). "The project-management approach in the "systematic management" of innovative start-up firms." Journal of business venturing 1(2): 149-160.

Diamond, D. W. and P. H. Dybvig (1983). "Bank runs, deposit insurance, and liquidity." Journal of political economy 91(3): 401-419.

Dishaw, M. T. and D. M. Strong (1999). "Extending the technology acceptance model with task-technology fit constructs." Information \& management 36(1): 9-21.

Eurostat, O. (2005). "Oslo Manual." The Measurement of Scientific and Technological Activities. Guidelines for Collecting and Interpreting Innovation Data.

Faber, J. and A. B. Hesen (2004). "Innovation capabilities of European nations: Cross-national analyses of patents and sales of product innovations." Research Policy 33(2): 193-207.

German, L., et al. (2013). "Contemporary processes of large-scale land acquisition in Sub-Saharan Africa: legal deficiency or elite capture of the rule of law?" World Development 48: 1-18.

Gikandi, J. W. and C. Bloor (2010). "Adoption and effectiveness of electronic banking in Kenya." Electronic commerce research and applications 9(4): 277-282.

Group, W. B. (2013). Global financial development report 2014: Financial inclusion, World Bank Publications.

Grundiche, Y. (2004). Marketing Strategy and Plans: Organizational Perspectives, Chicago. The Dryden Press.

Hall, B. H. (2004). Innovation and diffusion, National Bureau of Economic Research.

Ho, L.-A. (2011). "Meditation, learning, organizational innovation and performance." Industrial Management \& Data Systems 111(1): 113-131.

Holmstrom, B. (1989). "Agency costs and innovation." Journal of Economic Behavior \& Organization 12(3): $305-$ 327.

Joe, T. and H. F. Montgomery (2003). Service innovation: organizational responses to technological opportunities and market imperatives, World Scientific.

Kapur, D., et al. (2011). The World Bank: its first half century, Brookings Institution Press.

Kearns, G. and A. Lederer (2001). "Strategic IT alignment: a model for competitive advantage." ICIS 2001 Proceedings: 2.9

Kimingi, C. N. (2010). "The effects of technological innovations on the financial performance of the commercial banks in Kenya." Unpublished MBA project, University of Nairobi.

King, R. G. and R. Levine (1993). "Financial intermediation and economic development." Capital markets and financial intermediation: 156-189.

Lawson, B. and D. Samson (2001). "Developing innovation capability in organisations: a dynamic capabilities approach." International journal of innovation management 5(03): 377-400.

Leitch, S. and S. Davenport (2003). "Strategic ambiguity in communicating public sector change." Journal of communication Management 7(2): 129-139.

Lepetit, L., et al. (2008). "Bank income structure and risk: An empirical analysis of European banks." Journal of banking \& finance 32(8): 1452-1467.

Linck, K., et al. (2006). "Security issues in mobile payment from the customer viewpoint."

ling Guo, L., et al. (2017). "The interaction effects of environmental regulation and technological innovation on regional green growth performance." Journal of cleaner production 162: 894-902.

Lööf, H. and A. Heshmati (2006). "On the relationship between innovation and performance: A sensitivity analysis." Economics of Innovation and New Technology 15(4-5): 317-344.

Lys, T. and R. L. Watts (1994). "Lawsuits against auditors." Journal of accounting research 32: 65-93.

Manual, O. (2005). Guidelines for collecting and interpreting innovation data, OECD Paris.

Manual, O. (2005). "Guidelines for collecting and interpreting innovation data (2005)." A joint publication of OECD and Eurostat, Organization for Economic Co-Operation and Development. Statistical Office of the European Communities.

Mbiti, I. and D. N. Weil (2015). Mobile banking: The impact of M-Pesa in Kenya. African Successes, Volume III: Modernization and Development, University of Chicago Press: 247-293.

Misati, R. N., et al. (2010). "Financial innovation and monetary policy transmission in Kenya." International Research Journal of Finance and Economics 50: 123-136.

Mishra, P. K. (2008). "Financial innovation and economic growth-a theoretical approach." Available at SSRN 1262658.

Moghavvemi, S., et al. (2012). "Competitive advantages through IT innovation adoption by SMEs." Socialinės 
technologijos/Social Technologies 2(1): 24-39.

Mwangi, I. W. and M. M. Sichei (2011). "Determinants of access to credit by individuals in Kenya: A comparative analysis of the Kenya National FinAccess Surveys of 2006 and 2009." European Journal of Business and Management 3(3): 206-227.

Noyer, C. (2007). "Financial Innovation." Monetary Policy, and Financial Stability, Speech 17.

Omwami, E. M. and R. K. Omwami (2010). "Public investment and the goal of providing universal access to primary education by 2015 in Kenya." International Journal of Educational Development 30(3): 243-253.

Rajapathirana, R. J. and Y. Hui (2018). "Relationship between innovation capability, innovation type, and firm performance." Journal of Innovation \& Knowledge 3(1): 44-55.

Safarzyńska, K. and J. C. van den Bergh (2017). "Integrated crisis-energy policy: Macro-evolutionary modelling of technology, finance and energy interactions." Technological Forecasting and Social Change 114: 119-137.

Sahin, I. (2006). "Detailed review of Rogers' diffusion of innovations theory and educational technology-related studies based on Rogers' theory." Turkish Online Journal of Educational Technology-TOJET 5(2): 14-23.

Santos, J. B. and L. A. L. Brito (2009). "Toward a measurement model for firm performance." ENCONTRO DE ESTUDOS EM ESTRATÉGIA-ANPAD 4: 1-16.

Sohn, S. Y. and C. S. Jung (2010). "Effect of creativity on innovation: do creativity initiatives have significant impact on innovative performance in Korean firms?" Creativity Research Journal 22(3): 320-328.

Solow, R. M. (1957). "Technical change and the aggregate production function." The review of Economics and Statistics: $312-320$.

Soludo, C. (2005). "A keynote address delivered at the inauguration of the National Payments System Committee (NPSC) at Central Bank of Nigeria head office." Abuja,(May, 2005).

Tavitiyaman, P., et al. (2012). "The effect of competitive strategies and organizational structure on hotel performance." International Journal of Contemporary Hospitality Management 24(1): 140-159.

Venkatesh, V. and F. D. Davis (2000). "A theoretical extension of the technology acceptance model: Four longitudinal field studies." Management science 46(2): 186-204.

Volberda, H. W., et al. (2013). "Management innovation: Management as fertile ground for innovation." European Management Review 10(1): 1-15.

Vyas, V. (2009). Innovation and new product development by SMEs: An investigation of Scottish food and drinks Industry, Edinburgh Napier University.

WACHIRA, E. and M. H. Ondigo (2016). "The effect of technological innovation on the financial performance of commercial banks in Kenya." International Journal of Finance and Accounting 1(2): 61-76.

Wald, J. K. (1999). "How firm characteristics affect capital structure: an international comparison." Journal of Financial research 22(2): 161-187.

Wang, Q., et al. (2016). "Two-stage innovation efficiency of new energy enterprises in China: A non-radial DEA approach." Technological Forecasting and Social Change 112: 254-261.

Waweru, N. and G. Spraakman (2012). "The use of performance measures: case studies from the microfinance sector in Kenya." Qualitative Research in Accounting \& Management 9(1): 44-65.

Yang, J. and H. Lan (2010). The Moderating Role of Organizational Learning in the Relationship between Organizational Innovation and Performance. 2010 International Conference on Management and Service Science, IEEE.

Yeh-Yun Lin, C. and M. Yi-Ching Chen (2007). "Does innovation lead to performance? An empirical study of SMEs in Taiwan." Management Research News 30(2): 115-132.

Zhao, X. and B. Sun (2016). "The influence of Chinese environmental regulation on corporation innovation and competitiveness." Journal of cleaner production 112: 1528-1536. 